\title{
German-French squabble casts pall over prospects for LHC funding
}

Lausanne. Hopes for an agreement later this month on the financing of Europe's nextgeneration particle accelerator, the Large the European Laboratory for Particle Physics (CERN), are looking decidedly forlorn.

CERN's two host countries - France and Switzerland - are still refusing to meet the demands of two other major member states, Germany and the United Kingdom, that they should pay 10 per cent of the total LHC costs in addition to their normal CERN contributions.

Last week the two countries agreed to offer a 4.3 per cent surcharge. But this level is too low to satisfy Germany and the United Kingdom. These argue that 10 per cent is the norm for countries hosting large internaEuropean Synchrotron Radiation Facility (ESRF) in France and Joint European Torus (JET) in the United Kingdom.

Burt Richter, director of the Stanford Linear Accelerator Center in California, and Hirotaka Sugawara, director of KEK, the Japanese particle physics laboratory, both warned this week that if agreement is not reached by the end of September, CERN risks losing the participation of their respective countries.

The LHC will cost CERN's 19 member Hadron Collider (LHC) being planned by tional science facilities, for example the

states SFr2.6 billion (US $\$ 2.02$ billion). But only SFr2.1 billion is to be paid for out of normal subscriptions. The SFr500 million deficit could be eliminated by stretching the programme over an extra two years, although the suggestion is not popular with physicists keen for large experiments to continue uninterrupted.

Christopher Llewellyn Smith, CERN's director-general, wants non-member countries to make up the difference. And after the decision by the US Congress last autumn to pull the plug on the Superconducting Super Collider, particle physicists in the United States and Japan have been turning to the LHC to fulfill their ambitions.

But Sugawara warned delegates at a meeting on large facilities in physics organized in Lausanne by the European Physical Society that CERN was developing a reputation for political infighting. Continued failure to reach agreement had prevented scientists from putting forward a convincing case to their governments, he said, and if they had to wait too long, their interest may have waned.

The LHC hit problems at CERN's June council meeting. Germany, backed by the United Kingdom, unexpectedly demanded that France and Switzerland pay a surcharge of SFr260 million in recognition of the

\section{UK funds more science for the people}

\begin{abstract}
London. The Molecule
Theatre Company

(right), a group which mounts performances almed at introducing seven- to 11-year-old children to basic scientific ideas, is one of a number of organizations that will receive grants from Britain's Office of Sclence and Technology for furthering the public understanding of science.
\end{abstract}

Announcing the grants last week at the annual meeting of the

British Association for the Advancement of Science, David Hunt, the minister for science, added that some of the money would support a national "science week" next March, a sequel to the first such event held earlier this year.

Hunt also announced that a two-tier system, to be managed by the Royal Society through the Committee for the Public Understanding of Science, is to be established for handling awards in the field. One will be a 'seed fund' for small-scale local projects, and the other a 'development fund' for larger initiatives. The Molecule Theatre is to receive a grant of $£ 30,000$ over three years. This year's production, The Bottle Garden, Includes a scene in which two "dolphins" (Gerard Bell and Stephen McEachran) show how the oxygen and ozone molecules are formed (see also page 192.) economic advantages the two countries obtain as host countries (CERN straddles the border between the two near Geneva). Negotiations over summer have led to a considerable increase in their initial offer of SFr25 million; but it is still well short of the German-UK demand.

The United Kingdom was prepared to compromise, and is reported to have been considering a diplomatic "redefinition" of what constitutes 10 per cent. The suggestion was that the figure could be considered as a fraction of the two countries' annual contributions of around SFr200 million over the expected 10-year duration of the programme, rather than a fraction of the whole bill. The accumulated total - SFr200 million would represent around 7 per cent of the total costs.

Germany is said to have been much more intransigent. Its stubbornness is largely due to the financial pressures on all of its public spending since reunification. But Germany is also standing firm on the principle that as France and Switzerland reap a greater share of the benefits of CERN than other member states, they should pay extra for it.

"Principles are harder to fight than anything," says Hubert Curien, president of CERN council, who is trying to negotiate a middle ground. He believes that the host countries have greatly improved their offer, and that in any case LHC is not equivalent to ESRF and JET because it uses existing facilities (LHC will use the same 27-metre tunnel as the currently running particle accelerator LEP).

Curien suggests that, as Germany has been given a special dispensation for several years to keep its CERN contributions related to the GNP of its western states alone, rather than that of the whole country (as membership rules require), it might in turn be prepared to compromise. Both French and Swiss science are currently facing cuts in their budgets, and neither will find it easy to raise their offer.

While each side has its own troubles, the warring factions are busy blaming each other. The French say that the German demands are too high and unreasonable; the Germans accuse the French of unfairly exploiting other CERN member states by not paying for everything they get.

To limit possible further public embarrassment, Curien says that he may delay the CERN council meeting planned for $30 \mathrm{Sep}-$ tember until he is absolutely certain of agreement. But he insists that negotiations are not at an impasse, and remains confident of a positive decision by the end of the year. "If it does not happen, it will be very bad for physics," he says.

Allson Abbott 